\title{
Bemutatkozik az EDUVITAL: egy hazai ifjúsági egészségtudatossági és -nevelési program
}

\author{
On the EDUVITAL: A Hungarian youth health awareness \\ and education program
}

\author{
Szerző: Falus András $\bowtie$ \\ Semmelweis Egyetem, Genetikai, Sejt- és Immunbiológiai Intézet
}

Beküldve: 2018. 02. 11.

doi: $10.24365 /$ ef.v59i1.238

Kulcsszavak: egészségtudatosság, epigenetika, életmód, komplex egészségnevelés, kortársoktatás

Keywords: health awareness, epigenetics, way of life complex health education, peer education

2012 januárja óta múködik az EDUVITAL Nonprofit Egészségnevelési Társaság. A szerveződés szakértői csapata az egészségre (= EGÉSZ-SÉG) vonatkozó sokoldalú oktatási-nevelési programokat kutat és fejleszt, elsősorban az ifjúságra közvetlenül ható szakemberek (pedagógusok, pszichológusok, háziorvosok, szociológusok, védőnők, lelkipásztorok, szociális munkások) és szülők számára. A nonprofit szervezetet néhai Kopp Mária professzorasszony és Falus András professzor alapították.

\section{BEVEZETÉS}

A magyar társadalom jelenlegi egészségi állapota és távlati kilátásai korántsem mondhatóak felhőtlennek. Kopp Mária és Skrabski Árpád tanulmányai (Hungarostudy sorozat és egyebek) erre már korábban is felhívták a figyelmet. Az azóta tovább romló helyzet minden felelősen gondolkodó szakember számára azonnali, kötelező és hosszú távú feladatokat jelöl ki. Ennek felismerése is hozzájárult az EDUVITAL kezdeményezés sikeréhez.

Hat éve, több hazai állami és egyházi fenntartású egyetem részvételével, az MTA Elnöki Oktatási Bizottságának és a Tudományos Ismeretterjesztő Társaságnak a támogatásával orvosok, pedagógusok, biológusok, pszichológusok, lelkészek, szociológusok, bioetikusok és egészségtudományi szakemberek életre hívták az EDUVITAL Nonprofit
Egészségnevelési Társaságot (www.eduvital.net), amely ma már Alapítvány formájában is múködik. Az "alulról kezdeményezett” szervezet megalapítását különleges multidiszciplináris összefogás eredményezte, amelyhez azóta nagyon sokan, nagyon sokféle háttérrel csatlakoztak.

Nézeteink szerint az egészségtudatosság-egészségfejlesztés jelentős mértékben függ a korszerü, sokoldalú pszichoszociális-, szociológiai- és orvosbiológiai tudás széles körű hozzáférhetőségétől, valamint ezzel együtt a társadalom tagjainak személyes motivációjától is. Ezért közös feladat és felelősség, hogy a prevenciós, egészségnevelési feladatok sokkal markánsabb részt kapjanak. Ebből következik a pedagógiai, háziorvosi, iskola-, foglalkozás- és környezet-egészségügyi ellátás prevenciós szemléletű átalakításának még hangsúlyosabbá tétele.

A proaktív interakció a szakember és az egyén között minden korosztályban lényeges, de az egészséges életvitel jövőbeli mintázatának alakítása és az elért eredmények fenntarthatósága szempontjából különös figyelmet érdemel a jövő nemzedék, a gyermekek és a fiatal korosztály.

\section{AZ EDUVITAL MOZGALOM CÉLA ÉS TEVÉKENYSÉGE}

Az egyre szélesebb körben ismert EDUVITAL mozgaIom célja, hogy komplex, átfogó és a gyakorlati 
munkában, tanácsadásban jól használható, felelősségteljes információkat és alkalmazható pedagógiai technikákat dolgozzon ki és terjesszen az egészségnevelés- és fejlesztés területén.

Az EDUVITAL tevékenysége kiterjed a tudományosságon alapuló, alapvető orvosbiológiai, epigenetikai, táplálkozásbiológiai, mozgási, mentális és fizikai higiéniai, szenvedélybetegségekre vonatkozó, pszichológiai, esztétikai és szociológiai ismeretekre. A célcsoport, az $x$, y és $z$ generáció digitális motiváltsága miatt az írott formák mellett, a multimédiás és internetes (például: webinarok, honlapok, Facebook stb.) formátumú oktatási anyagok létrehozására, optimalizálására és széles körű terjesztésére van szükség. A jelenkori korszerútlen hazai oktatáspolitika egyik súlyos, és a magyar társadalom jövőjére nézve tragikusan ható hiányosságának tartjuk a túlzsúfolt, lexikális tudásra alapozó közoktatási koncepcióban az egészségnevelés és a primer prevenciós szemlélet markáns hiányát, illetve leglátványosabban a szakképzésben brutálisan érvényesülő kapkodó és voluntarista fünyíró szemléletet. Központi oktatáspolitikai kérdésnek tartjuk, és minden tevékenységi formában aktívan teszünk azért, hogy kiemelt szerepet kapjanak az alap- és középszintű oktatásban a lelki-testi egészség, a mentálhigiénia, a pszichoszomatikus kórképek kérdései, a család és a bioetika legfőbb elemei is. Ennek alapján az EDUVITAL állandó nemzetközi kitekintéssel nyilvános szakmai, interdiszciplináris dialógust kezdeményezett és teszi ezt folyamatosan az orvosi, viselkedésgenetikai-, pszichológiai és szociológiai tudományok fejlődésével kapcsolatos dilemmákról, a hagyományos egészségnevelést és orvoslást ebben a keretrendszerben megújítani kívánó szakmai kezdeményezésekről.

\section{AZ EDUVITAL EDDIGI LEGNAGYOBB VÁLLALKOZÁSA: EGÉSZSÉGNEVELÉS KORTÁRSOKTATÁSSAL - TANUL, TANITSSD, TUDD (TANTUDSZ) (MTA PÁLYÁZAT)}

Az EDUVITAL elnyerte az MTA által 2015-ben, majd 2016-ban meghirdetett egy-, illetve négyéves Szakmódszertani (Tantárgyfejlesztési) kutatási pályázatot. A jelenleg hat középiskola és tíz közoktatásban résztvevő pedagógus bevonásával zajló egészségnevelési-pedagógiai kutatási munkában két egyetemi Kar, a Semmelweis Egyetem Egészségtudományi
Karának és az ELTE Tanító- és Óvóképző Karának oktatói, tanárai egymás tudását és motivációját kiegészítő módon közösen vesznek részt. A projekt új pedagógiai innovációkkal olyan hallgatók képzését dolgozza ki, akik az elsajátított egészségfejlesztési és egészségpedagógiai ismeretek, készségek és képességek birtokában alkalmasak középiskolai tanulók körében kortárs segítő feladatok ellátására. A képzési modell része az is, hogy felkészítsenek és irányítsanak pedagógus, illetve egészségtudományok képzésében résztvevő felsőoktatási hallgatókkal együtt középiskolai tanulókat - folyamatos szakmai kontroll mellett - óvodás, általános- és középiskolás (3-20 éves) gyermekek, tanulók körében végzendő, korosztályspecifikus és innovatív egészségfejlesztő tevékenységekre. A kortárs program az egészséges táplálkozáshoz és mozgáshoz, a megfelelő higiénés magatartáshoz, valamint a lelki egészséghez kapcsolódó ismeretek és attitűdök fejlesztési területeihez kapcsolódik. Az első év során 46 TANTUdSZ munkatársunk dolgozott a projektben és mintegy 630 közoktatásban résztvevő hallgató körében végeztünk kézhigiéniai, folyadékfogyasztási és újraélesztési képzést. A TANTUdSZ tematika hamarosan kiegészül drogprevenciós, stresszoldási és testmozgás projektekkel.

\section{SZÉLES SPEKTRUMÚ SZAKEMBERGÁRDA EGYÜTTMŰKÖDÉSE AZ EGÉSZSÉGNEVELÉS FOLYAMATÁBAN}

Közismert és többszörösen bizonyított tény, hogy az epigenetikai hatások sokfélesége (táplálkozás, mozgás, dohányzás, alvásmennyiség, stressz, pszichoszociális családi-, környezeti-közösségi ingerek) és ezek együttese számos tudatosan befolyásolható elemet tartalmaz.

Ennek megfelelően a tudatos döntéseinken alapuló életmód- és annak befolyásolható változtatása, komplex mentális epigenetikai spektrumot jelent, ami sokszínú szakmai összefogást és átgondolt, szakmailag megalapozott koordinációt kíván a szakemberektől.

Nagyon lényeges alapelv a komplexitás, hiszen a fizikai és mentális higiénia kérdései elválaszthatatlanok a környezet megóvása és a stresszkezelés kérdéseitől. Kiemelt jelentősége van a táplálkozási és mozgási kultúra mellett a múvészeteknek az egészség (azaz, egész-ség) megőrzésében és teljessé 
tételében. Mindezek megismertetése és „átélhetővé tétele" - különösen a fiatal generációk számára - minden kétséget kizáróan kulcskérdés a magyar társadalom jövőjét, versenyképességét és mentális kultúráját illetően.

Éppen ezért az EDUVITAL, nonprofit alapon, a testilelki egészségkultúra elterjesztésében érzi elhivatottnak magát. Szakembereink emberi elkötelezettsége egyidejüleg jelent biztosítékot a rangos tudományos színvonalra, valamint az empatikus, értékközpontú felelősségtudatra a jövő iránt.

\section{KAPCSOLÓDÁSI PONTOK}

Az EDUVITAL tevékenységét 2016-ig a Tudományos Ismeretterjesztő Társaság támogatta. Egyik lapjában, az Élet és Tudományban az EDUVITAL 2013 januárjától külön rovatban (Egészség-Egész-ség) hetente jelentkezett új, egészségbiológiai, egészségpszichológiai közleménnyel.

A változatos, különböző célcsoportoknak szóló programok, az írott és multimédiás anyagok az EDUVITAL honlapján (www.eduvital.net) és Facebook oldalán napról napra frissülve mindenki számára hozzáférhetők.

Az EDUVITAL NET és Alapítvány pályázatokból és szponzorok támogatásából szervezi programjait, állami támogatásban nem részesül.

\section{AZ EDUVITAL EDDIGI FŐBB TEVÉKENYSÉGEINEK RÖVID ÖSSZEFOGLALÁSA \\ (részletek: www.eduvital.net)}

- Az EDUVITAL felnőttképzési akkreditációt szerzett.

- A Semmelweis Egyetem Egészségtudományi Karán ETK-EDUVITAL előadássorozat kilencedik (kreditpontos) szemeszterét tartjuk.

- Az ELTE Tanító- és Óvóképző karán több éve egészségnevelési stúdiumokat tartunk.

- Az egyházi felsőoktatási intézményekben az EDUVITAL rendszeres oktatási és továbbképzési tevékenységet végez.

- Az Élet és Tudományban 2013-tól négy éven át múködött az Egészség=Egész-ség rovat, mely- ben kb. 200 cikk jelent meg az EDUVITAL gondozásában. A cikkek ma is letölthetők és olvashatók a www.eduvital.net honlapon.

- A MR1 „Közelről” című műsorának keretében 2013 óta folyamatosan, minden héten elhangzik egy EDUVITAL interjú, korábban néhai Vizy Dóra, jelenleg Bak Anita újságíró részvételével.

- Az EDUVITAL szülői- és diák fórumokat szervez többek között hátrányos helyzetű és roma településeken, tájékoztató előadásokat, egészségórákat tartanak szakembereink diákoknak.

- Az EDUVITAL együttmúködik, valamint közös hazai és nemzetközi szimpóziumokat tart az Amerikai Magyar Orvosszövetséggel.

- Együttmúködik a Tudományos Újságírók Klubjával.

- 2015-ben, majd 2016-2020 között az EDUVITAL csapat elnyerte az MTA Tantárgypedagógiai pályázati kírásán belül az Egészségnevelés Kortársoktatással - Tanulj, Tanítsd, Tudd (TANTUdSZ) c. pályázatát.

\section{KÖNYVKIADÁS}

Az EDUVITAL Múvek sorozat keretében eddig három könyvet adtak ki:

- Sokszínű egészségtudatosság. Értsd, Csináld, Szeresd (SpringMed, 2015, szerk. Falus András és Melicher Dóra)

- Zene és egészségnevelés. Új utak a zene megközelítéséhez. Módszertani segédlet pedagógusoknak interaktív zenés foglalkozások szervezéséhez (EDUVITAL, Székely Csilla Imola, 2015)

- Zene és Egészség (Kossuth Kiadó, szerk. Falus András, 2016)

Az EDUVITAL egyre szélesebb körből érkező résztvevőinek egységes véleménye, hogy az egyszerre több tudományterületet felölelő tájékozottság megannyi új gondolatot, ötletet, megvalósítási javaslatot szül, ezért is buzdít minden érdeklődőt, tanárt, egyetemi hallgatót és diákot egyaránt, hogy kapcsolódjon az EDUVITAL meggyőződésünk szerint jövőépítő tevékenységéhez. 